Provided for non-commercial research and education use. Not for reproduction, distribution or commercial use.

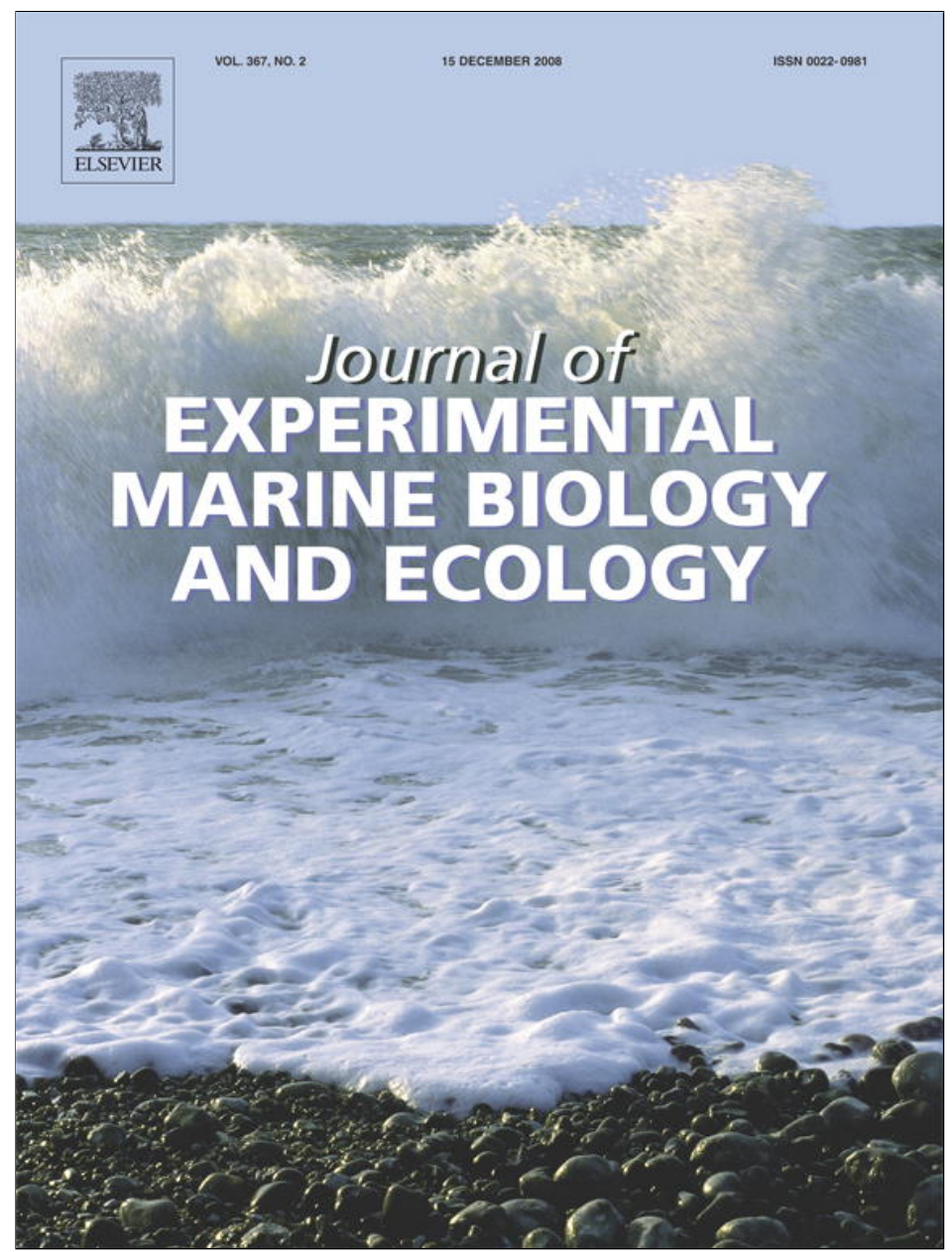

This article appeared in a journal published by Elsevier. The attached copy is furnished to the author for internal non-commercial research and education use, including for instruction at the authors institution and sharing with colleagues.

Other uses, including reproduction and distribution, or selling or licensing copies, or posting to personal, institutional or third party websites are prohibited.

In most cases authors are permitted to post their version of the article (e.g. in Word or Tex form) to their personal website or institutional repository. Authors requiring further information regarding Elsevier's archiving and manuscript policies are encouraged to visit:

http://www.elsevier.com/copyright 


\title{
Spring-neap cycle as a major driver of temporal variations in feeding of intertidal fishes: Evidence from the sea catfish Sciades herzbergii (Ariidae) of equatorial west Atlantic mangrove creeks
}

\author{
Uwe Krumme *, Matthias Brenner ${ }^{1}$, Ulrich Saint-Paul \\ Center for Tropical Marine Ecology (ZMT), Fahrenheitstr. 6, 28359 Bremen, Germany
}

\section{A R T I C L E I N F O}

\section{Article history:}

Received 27 October 2007

Received in revised form 28 August 2008

Accepted 28 August 2008

\section{Keywords:}

Ariid catfish

Block net

Mangrove creek

North Brazil

Sciades herzbergii

Spring tide

\begin{abstract}
A B S T R A C T
On macrotidal coasts, short- to medium term variations in feeding of intertidal fishes are influenced by several interacting time scales. To identify the driver of major variations in the feeding habits of intertidal fish, we used the pemecou sea catfish Sciades herzbergii (Ariidae), an abundant intertidal benthic second order consumer, as a model species. We analyzed the influence of the spring-neap and the day-night cycle on intertidal abundance, stomach fullness, diet composition and food consumption of $S$. herzbergii using block nets set at slack high tides in two mangrove creeks in north Brazil. At spring tides, intertidal abundance, stomach fullness, and total daily consumption of $S$. herzbergii were on average 8.8, 1.9, and 3.8 times higher than at neap tides, respectively. At spring tides, Uca spp. and Grapsidae (mostly Pachygrapsus gracilis) dominated the diet, irrespective of the time of day. Other important food items were Insecta and the semiterrestrial crab Ucides cordatus. At neap tides, Capitellidae contributed to the diet of nightly inundations while no specimens were caught at daytime. Creek location had no effect on any variable. Results from our study area and evidence from other studies suggest that the spring-neap tide pulse is likely the major driver of short- to medium term variations in feeding of intertidal fishes. This has important implications for feeding-related issues on macro- and probably also on mesotidal coasts: (i) juvenile fishes may have fortnightly growth spurts, (ii) intertidal prey populations may suffer regular fluctuations in mortality, (iii) studies of the feeding ecology of intertidal fishes should cover the combined effects of the tidal, diel, lunar and seasonal cycles, and (iv) the modeling of food webs should consider the differences between highly dynamic spring tide and quieter neap tide conditions.
\end{abstract}

(C) 2008 Elsevier B.V. All rights reserved.

\section{Introduction}

The intertidal zone provides important, although only temporary accessible foraging grounds for coastal fishes and other nektonic species. Many fish enter the intertidal zone to feed and it is therefore likely that the patterns in intertidal abundance correlate to some extent with patterns in feeding, although avoidance of predation, reproduction, and selection of appropriate environmental conditions may also explain changes in intertidal fish abundance (Gibson, 1992, 1996; Gibson et al., 1998; Rountree and Able, 1993). Studies on shortto medium time changes in intertidal fish abundance often highlight the importance of the spring-neap pulse and the day-night cycle for variation in assemblage structure (e.g. Gibson, 1988; Blaber et al., 1995; Laroche et al., 1997; Krumme et al., 2004), but the consequences for the trophic structure and feeding habits of the fishes have rarely been considered in detail (Wilson and Sheaves, 2001).

\footnotetext{
* Corresponding author. Tel.: +49 421 2380052; fax: +49 4212380030.

E-mail address: uwe.krumme@zmt-bremen.de (U. Krumme).

1 Present address: Alfred Wegener Institute for Polar and Marine Research (AWI), Am Handelshafen 12, 27570 Bremerhaven, Germany.
}

There are four environmental cycles that may influence the feeding habits of intertidal fishes on a time scale of hours to weeks: the floodebb tide, the day-night, the spring-neap, and the lunar cycle. These cycles may act in concert. The influence of the flood-ebb tide cycle usually results in emptier stomachs at flood tide and fuller stomachs at ebb tide when the fishes leave the intertidal foraging ground (e.g. Weisberg et al., 1981; Kleypas and Dean, 1983). The influence of the day-night cycle on feeding activity of intertidal fishes is speciesspecific and can interact with the tide (e.g. Kleypas and Dean, 1983; Beyst et al., 2002). In contrast to the two previous temporal cycles, the influence of the spring-neap tide cycle on feeding of fishes has rarely been studied. Hamerlynck et al. (1993) and Hampel and Cattrijsse (2004) found fuller fish stomachs at spring tide. We are not aware of any information on the influence of the lunar cycle on feeding behaviour of intertidal fishes. Krumme (unpublished data) found no effect of the four lunar phases on the feeding activity of the sea catfish Cathorops sp. in a north Brazilian mangrove creek. Likewise, Quinn and Kojis (1981), Rooker and Dennis (1991) and Krumme et al. (2004) found no differences in fish abundance between moon phases. As the factor moon phase can only be sampled once every month, it is difficult to collect a sufficiently high number of temporal replicates 
within a short time period to avoid mixing of monthly variations with variations related to the moon phase. Although most of the studies covered the simultaneous influence of two or three temporal cycles on the feeding activity of fishes, unfortunately, few studies come from tropical environments and spatial differences are rarely included in the sample design. In particular, information on temporal variations in feeding of intertidal fishes from mangrove environments (see Brenner and Krumme, 2007), as well as data from a variety of species from a mangrove ecosystem, is very rare thus making determinations on general feeding patterns of intertidal fishes difficult.

Mangroves are characterized by a rich epibenthos, especially fiddler crabs of the genus Uca. In a north Brazilian mangrove, for instance, detritivorous crabs ( $>95 \%$ of biomass were fiddler crabs) accounted for almost $90 \%$ of total benthic macrofauna production in the intertidal zone (Koch and Wolff, 2002). Information on consumption per unit of biomass and a predator-prey matrix is required to model the trophic flow through an ecosystem (e.g. Wolff et al., 2000). However, scant attention has been paid to the temporal variability in epibenthos consumption by mangrove fish when compiling consumption estimates.

In the present study, we provide for the first time information on the temporal and spatial variation in feeding of the pemecou sea catfish Sciades herzbergii (Bloch, 1794) (Ariidae), a major predator of brachyuran crabs in north Brazilian mangroves. Sciades herzbergii ranges from the southern Caribbean to the state of Sergipe in east Brazil (Oliveira, 1972) and is one of the dominant fish species in intertidal mangrove creeks (Barletta et al., 2003; Krumme et al., 2004; Giarrizzo and Krumme, 2007) and a target species of the artisanal fisheries. Annual catches between 1997 and 2000 in Pará ranged from almost 3000 t to $4500 \mathrm{t}$ (Isaac et al., 2006). Despite its importance for the nearshore fishery and the mangrove food web, information on the biology and ecology of S. herzbergii is scarce (Luengo, 1973; Chacon et al., 1994). Bulhosa-Trejo and Mago (1980) studied ontogenetic changes in feeding of S. herzbergii from Venezuela and found that both juveniles and adults fed on Crustacea, fish, and plant matter; fish were numerically more abundant in the diet of juveniles. Giarrizzo and Saint-Paul (2008) analyzed seasonal changes in the diet of S. herzbergii from the Curuçá estuary, Pará, north Brazil. The diet was dominated by Ocypodidae and Grapsidae year-round with greater stomach fullness in the wet season. However, the putative seasonal effect of Giarrizzo and Saint-Paul (2008) was correlated with higher levels of intertidal inundation in the wet season months, thus impairing strong inference on seasonal changes.

The objectives of this study were to analyze changes in the intertidal abundance, stomach fullness, digestion stage, and diet composition of $S$. herzbergii according to the combination of the factors tide (spring and neap tide) and time of day (daytime and night) as well as spatial differences between two sites. We provide first estimates of the intertidal consumption for major prey items of S. herzbergii and analyzed the size distribution of Uca spp. and Grapsidae in the diet of different size classes of S. herzbergii. In addition, we provide some length relationships. Results from our study area and evidence from other studies from macrotidal coasts are used to emphasize the importance of the spring-neap tide pulse in controlling medium-term variations in feeding of intertidal fishes and to highlight implications for fish growth, prey populations, and trophic modeling.

\section{Materials and Methods}

\subsection{Study Area and study site}

The study area is located within the world's longest contiguous mangrove coast, covering about $650 \mathrm{~km}$ of coastline south-east of the mouth of the Amazon River (Kjerfve and Lacerda, 1993). The study was conducted in the blind ending channel Furo do Meio, a tidal tributary of the Caeté bay, situated north of Bragança (Pará, Brazil) (Fig. 1). The
Furo do Meio is approximately $4.5 \mathrm{~km}$ long, draining the central part of a $180 \mathrm{~km}^{2}$ mangrove peninsula dominated by Rhizophora mangle $\mathrm{L}$., intermixed with Avicennia germinans (L.) at more elevated sites. The semidiurnal tide ranges from 2-3 $\mathrm{m}$ at neap to 3-4 $\mathrm{m}$ at spring tides in the mangrove creeks. The mangrove plateau is only flooded at spring tides. Water temperatures range between $25^{\circ} \mathrm{C}$ and $31^{\circ} \mathrm{C}$. Salinity in the Furo do Meio can fall below 5 in the wet season (January to June) and exceed 35 in the dry season (July to December).

\subsection{Sampling}

We define the stream order as follows: no order is assigned to the subtidal section, intertidal creeks draining into the subtidal section are 1 st order creeks. In order to study temporal and spatial changes in feeding and abundance of $S$. herzbergii, two 1st order creeks were blocked at slack high water (HW), one in the upper and the other in the lower reaches of the Furo do Meio (ca. $2 \mathrm{~km}$ apart) (Fig. 1) between 16th March and 9th May 2001 (wet season). Salinities were generally low, increasing from 5 in March to 12 in May. In the upper reaches of the Furo do Meio both the intertidal and the subtidal zone are mud while in the lower reaches only the intertidal section is mud. The subtidal section is sandy.

During two consecutive lunar cycles 32 block net samples were realized ( $30 \times 3 \mathrm{~m}, 25 \mathrm{~mm}$ stretched mesh size). The different moon/ tide phases and day-night changes result in four treatment groups: spring tide-night, spring tide-day, neap tide-night and neap tide-day; for the remainder of this paper they are denoted as SN, SD, NN and ND, respectively. HW at SN, SD, NN and ND occurred at ca. 19:00, 07:00, 01:00 and 13:00 local time, respectively. During each moon phase, four consecutive tidal cycles were sampled in the sequence "upper creek at night, upper creek at daytime, lower creek at night, lower creek at daytime". At three strong spring tides, the sampling was interrupted to save the net. Sciades herzbergii already entangled in the net were collected but only used for stomach analysis. Fish were collected at low water (LW). Our stomach fullness values are conservative estimates because the ongoing digestion during ebb tide until the fish were dissected in the field (see below) may have lead to an underestimate of the amounts eaten in the creek. The length of time until the fish were dissected was equal for all samples (ca. 6 hs after slack HW) so that no bias due to temporal changes in digestion stage was added. Altogether, 29 block net samples were used to compare abundances; in the upper creek 3, 3, 4, 4 at SN, SD, NN, ND (sum: 14) and in the lower creek 4, 3, 4, 4 at SN, SD, NN, ND (sum: 15), respectively.

After the sampling period the creeks were surveyed to provide an estimate of the area $\left(\mathrm{m}^{2}\right)$ inundated at neap tides when the tidal inundation is restricted to the intertidal mangrove creeks. The upper creek $\left(15566 \mathrm{~m}^{2}\right)$ was approximately twice the size of the lower creek $\left(7693 \mathrm{~m}^{2}\right.$ ) (Fig. 1). Neap tide inundations are restricted to the network of creeks and therefore, surface area measurements taken once at slack neap high tide may be used as a coarse approximation for the general neap tide inundation area, despite variability in the submerged area between neap tides (Krumme et al., 2004). The number of S. herzbergii caught at spring tides was not standardized to density (fish $\mathrm{m}^{-2}$ ) because at spring tides the entire mangrove plateau was flooded.

Not one S. herzbergii was caught at ND. To avoid an incomplete design, the effect of time of day (daytime and nightly inundation) and creek (upper and lower creek) on changes in abundance $[\log (x+1)$ transformed] was tested separately for spring tides [2-factor analysis of variance (ANOVA)] and for neap tides (Kruskal-Wallis tests). To test whether abundances differed between spring and neap tides, the Kruskal-Wallis test was used; the respective time of day and creek groups were pooled. ANOVA was only used when the assumptions were fulfilled (Kolmogorov-Smirnov test for normal distribution and Cochran test for homoscedasticity). 


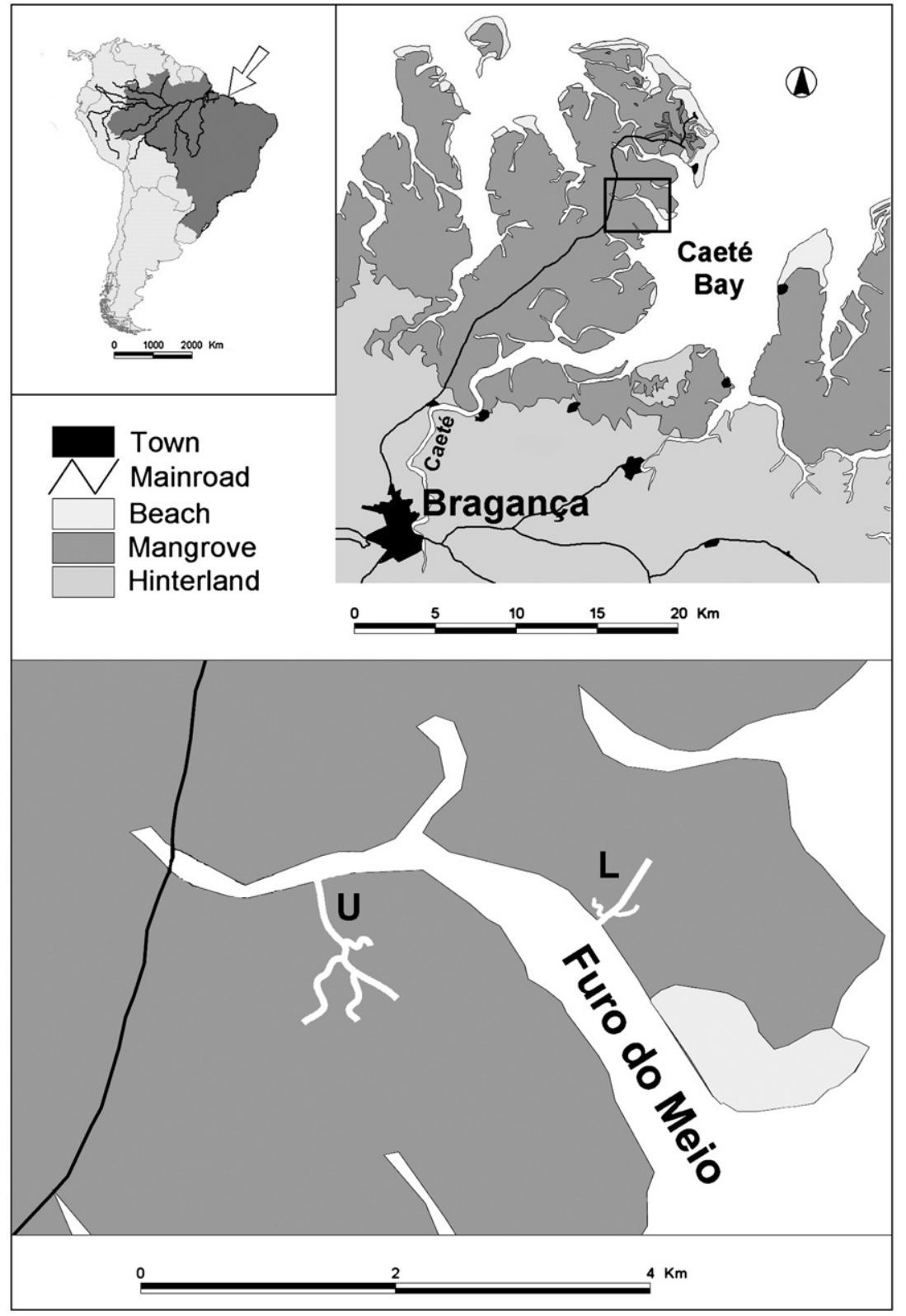

Fig. 1. Study area north of the city of Bragança (Pará, north Brazil) and two 1st order mangrove creeks in the upper (U) and lower (L) reaches of the Furo do Meio blocked between March and May 2001.

In the field, total length $(T L)$ to last full $\mathrm{cm}$ and total wet weight $(W \pm 1 \mathrm{~g})$ were determined. The fish were assigned to four size classes: $10-14 \mathrm{~cm} ; 15-19 \mathrm{~cm} ; 20-24 \mathrm{~cm} ; \geq 25 \mathrm{~cm}$ TL. The stomachs were removed and preserved in $10 \%$ formalin. Since many specimens were juveniles, fish were not separated into females and males. The length of the gastrointestinal tract (GIT) was measured from the esophagus to the anus $( \pm 0.1 \mathrm{~cm})$ and the relative length of the GIT was calculated $\left(G I T \times T L^{-1}\right)$. The feeding habit was classified according to Odum (1970) who suggested a relative stomach length of $<1,1-3$ and $>3$ for carnivorous, omnivorous, and herbivorous fish, respectively.

\subsection{Stomach fullness and Digestion stage}

In the laboratory stomachs $(n=147)$ were washed, drained on an absorbent paper and wet-weighed $( \pm 0.01 \mathrm{~g})$. Stomachs were opened and stomach fullness was assigned to five categories according to Dalpado and Gjøosæter (1988): empty; filled to 30\%; filled 30-70\%; filled $70-100 \%$; $100 \%$ full with stretched and thin walls. Stomach fullness index (SFI; see below) values were logistically transformed $[y=\ln (y /(100-y))]$. Similar to abundance, the effect of time of day and creek was analyzed separately, however, only for spring tide (2-factor ANOVA). To test whether SFI differed between spring and neap tides, 1 -factor ANOVA was used; the respective time of day and creek groups were pooled.

The digestion stage of the entire stomach content was assigned to four categories according to Dalpado and Gjøosæter (1988): recently eaten; <30\% digested; 30-70\% digested; $>70 \%$ digested. Stomach fullness and digestion stage of all fish analysed were assigned to the eight groups that resulted from the combination of the factors creek, tide, and time of day.

\subsection{Stomach content analysis}

Stomach contents were washed out onto a sieve (diameter $63 \mu \mathrm{m}$ ) and transferred to $50 \mathrm{ml}$ Kautex bottles (4\% formalin). Empty stomachs were drained and wet-weighed. The weight of the stomach 


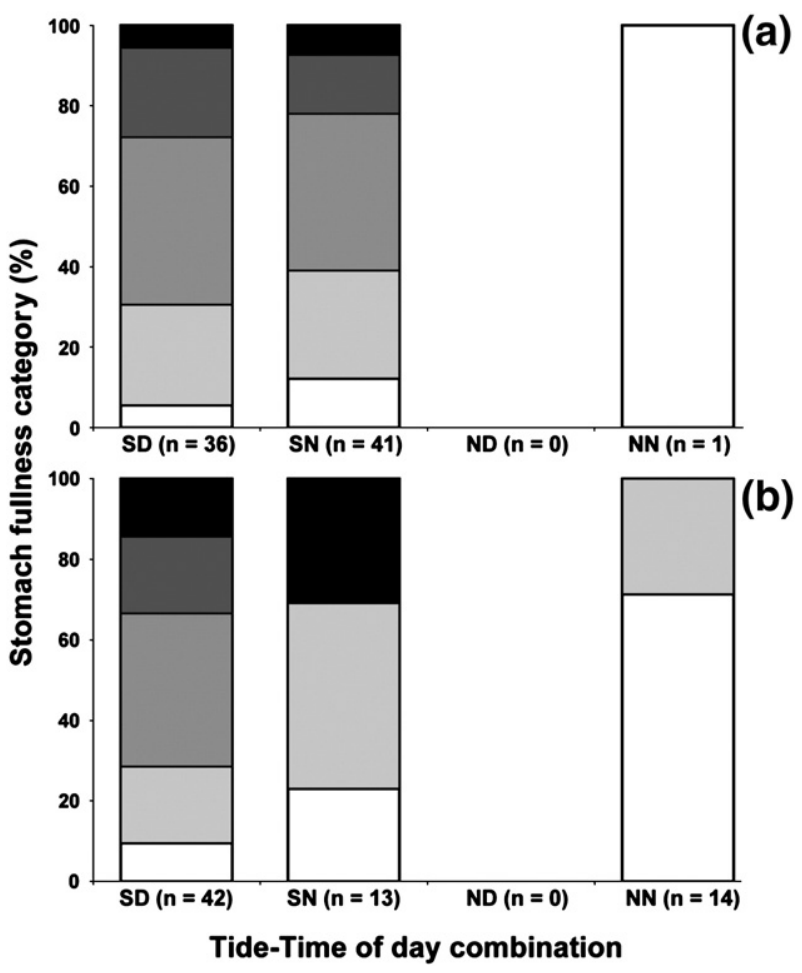

Fig. 2. Proportion of stomach fullness categories of S. herzbergii ( $100 \%$ stretched, 70 100\% filling, $\square$ 30-70\% filling, $\square<30 \%$ filling, $\square$ empty) from two 1st order mangrove creeks of the Furo do Meio (north Brazil) [(a): upper creek; (b): lower creek] at SD: spring tide-day, SN: spring tide-night, ND: neap tide-day and NN: neap tide-night. The number of stomachs analysed $(n)$ is given for each treatment combination. Fish were caught by blocking creeks at slack high water in the wet season 2001.

contents $\left(W_{\mathrm{S} \text { C }}\right)$ was calculated as $W_{\mathrm{S} \mathrm{C}}=W_{\mathrm{SF}}-W_{\mathrm{SE}}$; where $W_{\mathrm{S} \mathrm{F}}$ was the wet weight of the removed stomach $(\mathrm{g})$ and $W_{\mathrm{S}} \mathrm{E}$ was the wet weight of the empty stomach $(\mathrm{g})$. The stomach fullness index (SFI) was calculated as $S F I=\left[\left(W_{S} c \times\right.\right.$ total fish weight $\left.\left.{ }^{-1}\right) \times 100\right]$.

Contents were washed in distilled water to substitute formalin before contents were observed under a stereo magnifying glass and identified to the lowest possible taxon. Each taxon was briefly drained and then wet-weighed $( \pm 0.00001 \mathrm{~g})$. Items with less than $0.00001 \mathrm{~g}$ were included as $0.00001 \mathrm{~g}$. Whenever possible, fragments were assigned to the according taxon and weighed together. Unidentifiable fragments were weighed separately and assigned as "remain".

The carapace-width of all Crustacea in the stomachs was measured using the millimeter ocular scale $( \pm 0.5 \mathrm{~mm})$ of the stereo magnifying glass.

\subsection{Standardization of weights of food items}

The effect of fish size within the four different size classes was accounted for by standardizing stomach content weights to the geometrical mean weight of all investigated fish of one size class. According to Brenner et al. (2001) a linear regression between fish weight $\left(W_{\mathrm{F}}\right)$ and weight of empty stomach $\left(W_{\mathrm{ES}}\right)$ was established:

$W_{E S}=a+b \times W_{F}$

Subsequently, weight $\left(W \mathrm{P}_{j, i}\right)$ of each prey item $j$ found in the stomach of a fish $i$ of weight $W_{\mathrm{F} i}$ was standardized $\left(F_{\mathrm{S}}\right)$ using the geometrical mean weight $(G M)$ for the size class to which the fish with the $W_{\mathrm{F} i}$ belonged:

$W P\left(F_{S}\right)_{j, i}=W P_{j, i}(a+b \times G M) /\left(a+b \times W_{F i}\right)$

Using $y=0.0357 x-0.7449\left(R^{2}=0.96 ; n=147\right)$ the original stomach content weights were converted into standardized stomach content weights (Brenner et al., 2001).

\subsection{Feeding strategy and Food consumption}

The feeding strategy of $S$. herzbergii was assessed using the plot of Costello (1990). The prey-specific abundance was based on wet weights.

To determine the food consumption, individual SFI values were sorted according to the factor combinations SD, SN, ND and NN, and average SFIs for each group were calculated. The average SFIs of the daytime and the nightly inundation were added up to provide a measure of the daily consumption in \% body weight of $S$. herzbergii at spring and neap tide. This is not a conventional measure of evacuation rate. It was assumed that the stomach contents at the end of ebb tide were the minimum of what the fish had eaten and that the LW period was not a feeding period for S. herzbergii. Thus, the consumption calculated here is a conservative measure.

\subsection{Index of predation impact}

An index of predation impact for neap tides was measured as the weight of the main prey items eaten by S. herzbergii per hectare and day. The index was calculated according to Brewer et al. (1991) and Salini et al. (1998) as the product of predator biomass per tide $\left(\mathrm{g} \mathrm{ha}^{-1}\right)$ and the mean wet weight proportion of a prey item in the diet per tide. The predator biomass was only calculated for neap tides because no fish densities were determined for spring tides (see above under Sampling).

\section{Results}

\subsection{Intertidal Abundance}

A total of 292 S. herzbergii were caught from the two mangrove creeks. Abundances were significantly higher at spring tide than at

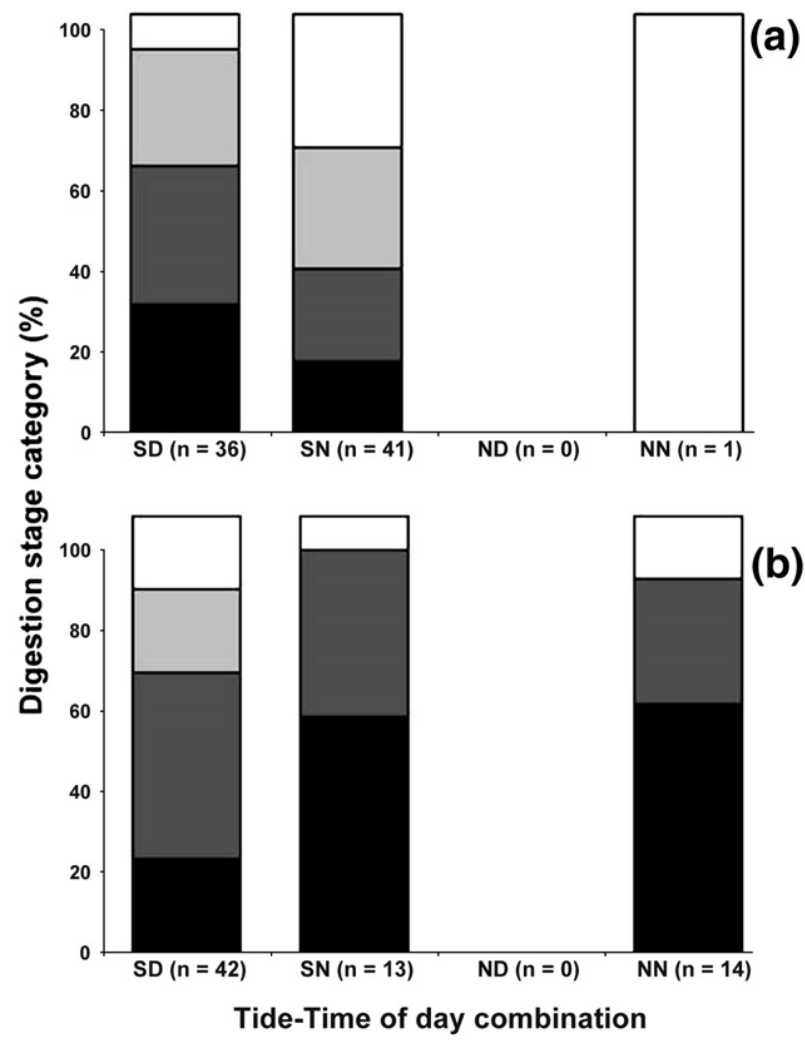

Fig. 3. Proportion of digestion stage categories of S. herzbergii ( $\square>70 \%$ digested, $\square 30$ $70 \%$ digested, $\mathbf{\square}<30 \%$ digested, $\mathbf{\square}$ ingested recently) from two 1 st order mangrove creeks of the Furo do Meio (north Brazil) [(a): upper creek; (b): lower creek] at SD: spring tide-day, SN: spring tide-night, ND: neap tide-day and NN: neap tide-night. The number of stomachs analysed $(n)$ is given for each treatment combination. Fish were caught by blocking creeks at slack high water in the wet season 2001. 


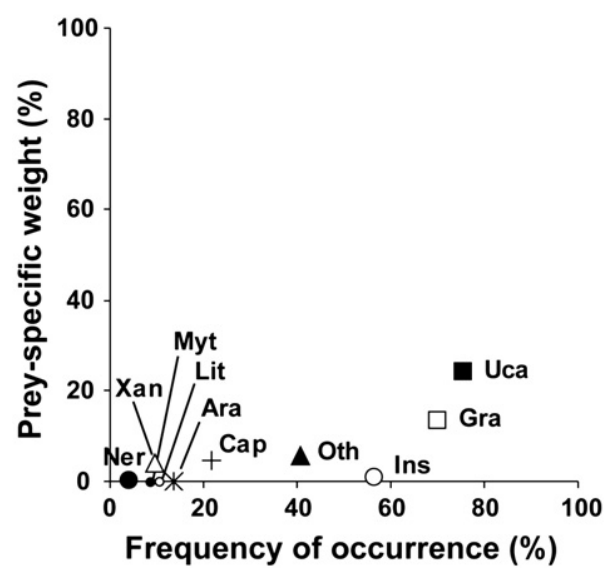

Fig. 4. Costello-plot for S. herzbergii $(n=147)$ caught in the mangrove channel Furo do Meio (north Brazil) in the wet season 2001. Food item abbreviations: Uca: Uca spp., Gra: Grapsidae, Ins: Insecta, Oth: Others (e.g. Ucides cordatus), Cap: Capitellidae, Ara: Aranae, Lit: Littorinidae, Myt: Mytilidae, Xan: Xanthidae (mostly Euryteum limnosum), Ner: Nereidae. neap tide (Kruskal-Wallis test, $H(1, n=29)=11.71, p<0.001)$. At spring tides, the factors time of day $(p>0.42)$ and creek $(p>0.86)$ had no significant effect on abundances and there was no interaction $(p>0.80)$ (2-factor ANOVA). At neap tides, abundances were significantly higher at night than at daytime (Kruskal-Wallis test, $H$ $(1, n=14)=5.02, p<0.025)$. Mean HW abundance of $S$. herzbergii at nightly neap tides was 0.0002 fish $\mathrm{m}^{-2} \pm 0.0001$ S.E.

\subsection{Stomach fullness and Digestion stage}

At spring tides, the factor time of day $(p>0.61)$ and creek $(p>0.84)$ had no effect on SFI and there was no significant interaction $(p>0.77)$ (2-factor ANOVA). However, the overall SFI at spring tides (mean: $2.43 \% \pm 1.93$ S.D.) was higher than at neap tides (mean: $1.25 \% \pm 0.89$ S.D.) (1-factor ANOVA, $F=5.35, p<0.0222$ ).

The proportions of the stomach fullness reflect the results of the univariate analysis (Fig. 2a,b). Stomachs were fuller at spring tide than at neap tide. At spring tide, there was no difference in the stomach fullness stage between daytime and night and between creeks. NN stomachs were empty or poorly filled (Fig. 2a,b). The absence of fish at ND and the capture of only one specimen at NN in the upper creek did
Upper creek

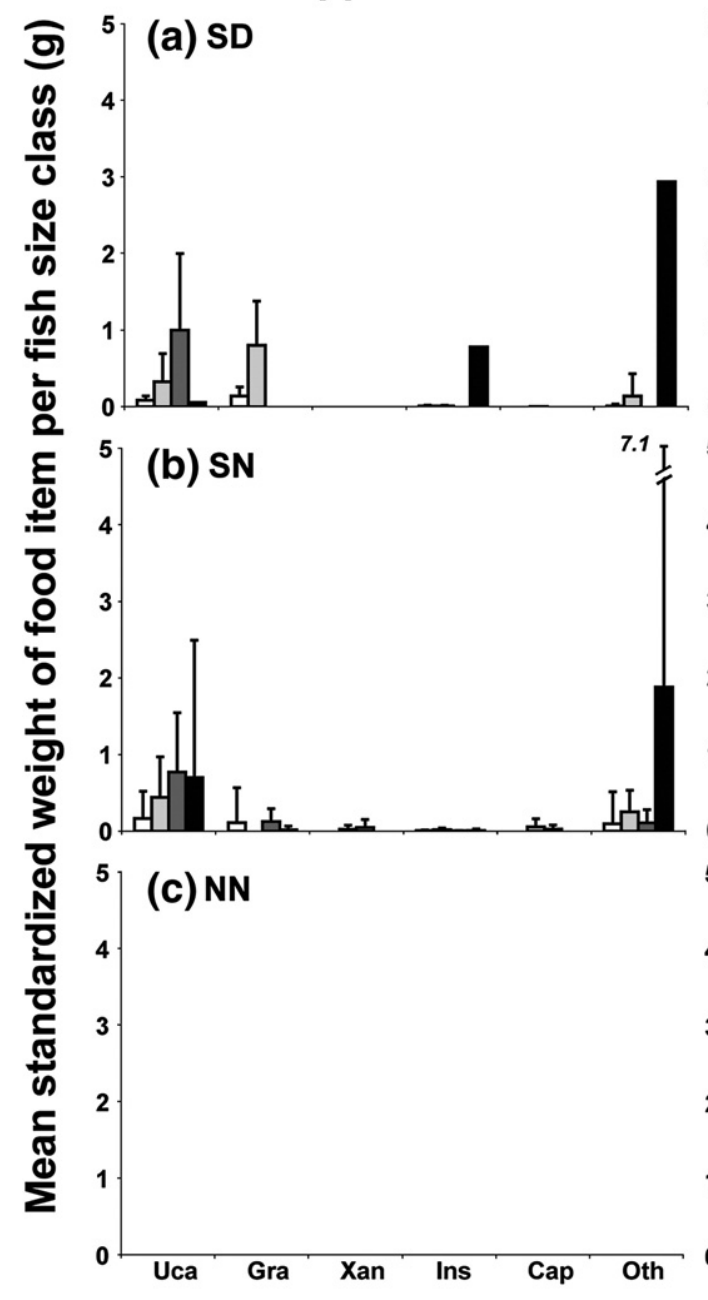

Lower creek

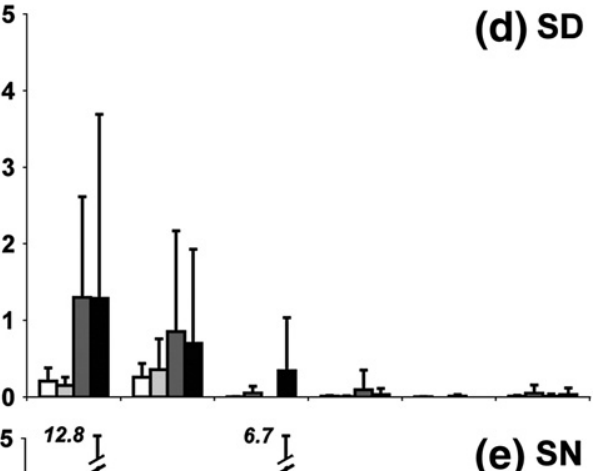

Food item

Fig. 5. Food composition of S. herzbergii ( $\mathrm{g}$ wet weight $+95 \% \mathrm{CI}$ ) caught at different combinations of the factors tide and time of day (spring tide-day (SD), spring tide-night (SN) and neap tide-night (NN); at neap tide-day no specimens were caught) from two 1st order intertidal mangrove creeks [(a-c)= upper creek, left column; (d-f)=lower creek, right column] in the wet season 2001 in the Furo do Meio near Bragança, north Brazil. The sample sizes according to the size classes ( $\square$ 10-14 cm, $\square 15-19 \mathrm{~cm}$, $\square 20$ - $24 \mathrm{~cm}$, $\mathbf{\square}>25 \mathrm{~cm} T L$ ) were: (a) 13,18, 4, 1; (b) 3, 14, 19, 5; (c) 0, 0, 0, 1 (empty stomach); (d) 12,11, 14, 5; (e) 0, 4, 6, 3; (f) 0, 2, 4, 8. Weights of food items were standardized per fish size class. Food items are abbreviated; Uca: Uca spp.; Gra: Grapsidae; Xan: Xanthidae; Ins: Insecta; Cap: Capitellidae; Oth: Others (Fig. 5a: large weight contribution was due to a single fish consumed). 
not allow for the analysis of diel and spatial patterns in feeding at neap tides.

The proportions of the digestion stages (Fig. 3a,b) showed no consistent temporal or spatial pattern. However, low stomach fullness and digestion stages at NN (Figs. 2b, 3b) led to the rejection of the assumption that a higher stomach fullness is correlated with a higher proportion of recently ingested food.

\subsection{Food analysis}

Sciades herzbergii has a short stomach with strong musculature. The mean relative length of the GIT was $1.60 \pm 0.18$ S.D. $(n=36) .147$ specimens were used for stomach analyses. Fig. 4 shows that S. herzbergii fed mainly on Uca spp. and Grapsidae (mostly Pachygrapsus gracilis), which were eaten by $76 \%$ and $70 \%$ of the fish, while their average contribution to the stomach content weight was $24 \%$ and $14 \%$, respectively. Other important food items were Insecta $(57 \%$ occurrence, $1 \%$ weight), Capitellidae (22\% occurrence, $5 \%$ weight) and Ucides cordatus (5\% occurrence, $11 \%$ weight). Less important were Araneae, Littorinidae, Mytellidae, Xanthidae and Nereidae (occurrence below $15 \%$, weight below 3\%). The item "Others" consisted of several rare taxa (Isopoda, Callinectes sp., Gnathidae, Amphipoda, shrimp and fish), occurring in $41 \%$ of the stomachs, however, only contributing $5 \%$ to the average stomach content weight. Sciades herzbergii exhibited a generalized feeding strategy with a high within-phenotype component where most of the individuals used many resource types simultaneously.

\subsection{Changes in diet composition}

Similar proportions of the major food items were ingested by all size classes at spring tides (Fig. 5a,b,d,e). However, the two largest size

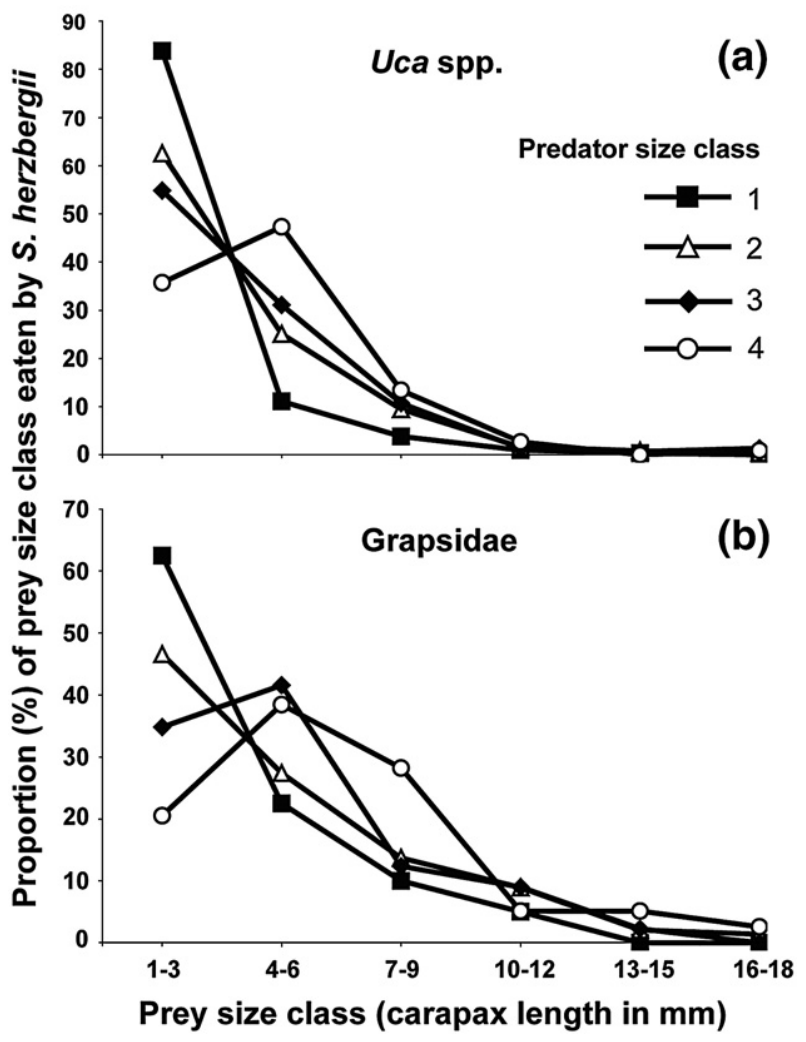

Fig. 6. Proportion of six prey size classes of (a) Uca spp. and (b) Grapsidae consumed by four predator size classes (S. herzbergii, Ariidae). The size classes 1 (10-14 cm TL), 2 (15$19 \mathrm{~cm}), 3(20-24 \mathrm{~cm})$, and $4(\geq 25 \mathrm{~cm})$ of S. herzbergii consumed 314, 220, 281, and 104 Uca spp., and 120,146, 89, and 39 Grapsidae, respectively.
Table 1

(a) Total mean ( \pm S.D.) consumption of S. herzbergii in \% body weight per semidiurnal tide and itemized for main food items; (b) mean daily consumption for spring tides (SD + SN) and neap tides (ND+NN). SD: spring tide-day; SN: spring tide-night; NN: neap tidenight; ND: neap tide-day

\begin{tabular}{lllllll}
\hline (a) & \multicolumn{7}{l}{} \\
\hline Combination & Total & Uca spp. & Grapsidae & Ucides cordatus & Capitellidae & $n$ \\
\hline SD & $2.56 \pm 1.98$ & $0.38 \pm 0.70$ & $0.66 \pm 0.97$ & $0.08 \pm 0.27$ & $0.003 \pm 0.01$ & 78 \\
SN & $2.19 \pm 1.88$ & $0.45 \pm 0.89$ & $0.18 \pm 0.35$ & $0.13 \pm 0.54$ & $0.03 \pm 0.12$ & 54 \\
NN & $1.25 \pm 0.89$ & $0.23 \pm 0.57$ & $0.12 \pm 0.33$ & $0.09 \pm 0.34$ & $0.38 \pm 0.34$ & 15 \\
ND & 0 & 0 & 0 & 0 & 0 & 0 \\
& & & & & & \\
(b) & & & & & & \\
\hline Tide & Total & Uca spp. & Grapsidae & Ucides cordatus & Capitellidae \\
\hline Spring & 4.75 & 0.84 & 0.84 & 0.21 & 0.03 \\
Neap & 1.25 & 0.23 & 0.12 & 0.09 & 0.38 &
\end{tabular}

Fish were caught from 1st order intertidal mangrove creeks near Bragança, north Brazil using a block net at slack high water from March-May 2001 (wet season). $n$ : number of specimens in each group.

classes had eaten greater amounts of food. The high weights of the food item "Others" in the largest size class-upper creek at SD and SN (Fig. 5a,b) resulted from unidentifiable crab material eaten by a single fish and from a belonid fish ingested by one out of five specimens at SN.

The diet composition was different between spring and neap tides. At NN Capitellidae were consumed in considerable amounts by all size classes sampled in the lower creek (Fig. 5f); only the two larger size classes still fed on crabs.

\subsection{Prey size distribution in the diet}

Ninety-five percent of Uca spp. and 90\% of Grapsidae ingested by S. herzbergii were smaller than $10 \mathrm{~mm}$ (Fig. 6a,b). The proportion of the smallest prey size class (1-3 mm carapax length) of Uca spp. and Grapsidae decreased with increasing predator size while the proportion of the 4-6 $\mathrm{mm}$ and the 7-9 $\mathrm{mm}$ size class increased with increasing predator size.

\subsection{Food Consumption}

On average the fish had eaten $2.3 \%$ of their wet weight per tide ( \pm 1.9 S.D.; range: $0-8.6 \% ; n=147$ ). The food consumption of S. herzbergii at SD, SN, NN, and ND is shown in Table 1a. While the mean consumption of Uca spp. and $U$. cordatus was similar at SD, SN and NN, the mean consumption of Grapsidae was highest at SD. In contrast, the consumption of Capitellidae increased one order of

Table 2

Predation impact of S. herzbergii on main food items expressed in grams of prey wet weight eaten per hectare per nightly neap tide

\begin{tabular}{|c|c|c|c|c|}
\hline & \multicolumn{2}{|l|}{ Upper creek } & \multicolumn{2}{|l|}{ Lower creek } \\
\hline & $\begin{array}{l}\text { Food item } \\
\text { proportion per tide }\end{array}$ & $\begin{array}{l}\text { Predation } \\
\left(\mathrm{g} \mathrm{ha}^{-1} \mathrm{tide}^{-1}\right)\end{array}$ & $\begin{array}{l}\text { Food item } \\
\text { proportion per tide }\end{array}$ & $\begin{array}{l}\text { Predation } \\
\left(\mathrm{g} \mathrm{ha}^{-1} \text { tide }^{-1}\right)\end{array}$ \\
\hline Uca spp & 0 & 0 & 0.24 & 539.50 \\
\hline Grapsidae & 0 & 0 & 0.13 & 276.23 \\
\hline $\begin{array}{l}\text { Ucides } \\
\text { cordatus }\end{array}$ & 0 & 0 & 0.09 & 204.25 \\
\hline Capitellidae & 0 & 0 & 0.40 & 889.38 \\
\hline $\begin{array}{l}\text { Predator } \\
\text { abundance }\end{array}$ & & 131.05 & & 2202.65 \\
\hline Consumption & & 0 & & 0.87 \\
\hline
\end{tabular}

Four block net samples were carried out in each creek in the wet season 2001 nea Braganca, north Brazil. Only one fish was caught in the upper creek (empty stomach) and 14 in the lower creek. The predation impact is the product of the abundance of S. herzbergii $\left(\mathrm{g} \mathrm{ha}^{-1}\right.$ tide $\left.^{-1}\right)$ and the mean proportion of the prey item in the diet per tide. Consumption is given in \% body weight of $S$. herzbergii per tide. 
magnitude from SD over SN to NN, respectively (Table 1a). The total consumption and the consumption of Uca spp., Grapsidae, U. cordatus was 3.8, 3.7, 7.2, and 2.5 times higher at spring tides than at neap tides while the consumption of Capitellidae was 13.1 times higher at neap than at spring tides (Table $1 \mathrm{~b}$ ). The mean daily consumption was $3.0 \%$ per body weight of $S$. herzbergii, considering both spring and neap tides.

The consumption estimate per biomass of $S$. herzbergii of the main food items could be calculated for nightly neap tides only because at ND not one specimen was caught. The estimate is further restricted because fish were mainly caught from the lower creek (Table 2). The mean consumption of the main food items at nightly neap tides from both creeks was $0.87 \%$ body weight of $S$. herzbergii per tide.

\section{Discussion}

\subsection{Spring-neap tide cycle}

Our results show that the spring-neap tide pulse was the most important cycle determining short- to medium term changes in feeding of $S$. herzbergii in the mangrove creek habitat. At spring tides, intertidal abundance, stomach fullness and total daily consumption of S. herzbergii were on average 8.8,1.9 and 3.8 times higher than at neap tides, respectively. The effect of the spring-neap tide pulse on the feeding activity was not only striking in S. herzbergii but also noticeable in three other abundant intertidal mangrove fish species from our study area. The mean daily consumption of both $A$. anableps and the ariid catfish Cathorops sp. were 1.6 times higher at spring tides (Brenner and Krumme, 2007; Krumme, unpubl. data), with a strong day-night interaction in A. anableps. The stomachs of the cocosoda catfish Pseudauchenipterus nodosus were significantly fuller at SN than at any other tide-time of day combination (Krumme et al., 2004). On the Kenyan coast which is also subject to strong semidiurnal tides, Colombini et al. (1996) found greater numbers of prey items in the stomachs of the mudskipper Periophthalmus sobrinus at spring than at neap tides. Also in Kenya, the swimming crab Thalamita crenata ingested greater quantities of food at spring than at neap tides (Cannicci et al., 1996).

Our studies from an equatorial west Atlantic mangrove environment, the two studies from Kenya and evidence from studies in temperate European tidal marshes (Hamerlynck et al., 1993; Hampel and Cattrijsse, 2004) suggest that intertidal fishes from coasts with semidiurnal macrotides and regular spring-neap tide cycles may generally encounter better foraging conditions during spring tides. Intertidal fishes from coasts of similar tidal regimes may adopt similar strategies to cope with the regular changes in intertidal accessibility. It is therefore likely that the importance of the spring-neap cycle in patterns of feeding of intertidal fishes found in our equatorial site is transferable to other coasts with similar tidal regimes, although obvious differences in the vertical distribution of prey items between ecosystems such as mangrove, salt marshes, rocky or sandy shores may lead to differing patterns.

A quasi-weekly alternation in the foraging success of intertidal fishes has important implications for at least four ecological aspects: (1) Growth periodicity of the fishes: The improved foraging conditions at spring tides suggest that the fish have a fortnightly growth periodicity with faster growth during spring tides. Findings of Rahman and Cowx (2006) from the coast of Bangladesh, which has a tide pulse similar to our study area in north Brazil, support this assumption. The otoliths of Tenualosa ilisha had narrow neap tide rings and wide spring tide rings. Fortnightly growth spurts are likely associated with steps in the ontogenetic development of juveniles and are possibly related to patterns in recruitment or susceptibility to predation and thus, to survival rates of cohorts. (2) Studies of the feeding ecology of intertidal fishes: Feeding studies of fishes should cover the full range of short- to medium-term temporal combinations to ensure that the results provide a comprehensive picture of the variations in food quantity and quality of a fishes' diet (lunar cycle in clearer waters, spring-neap tide and day-night cycle and their interactions). If we had sampled at neap tides only, we would have considered S. herzbergii a polychaete feeder specialized on Capitellidae. We would have mistakenly described a niche overlap with Cathorops sp., another abundant ariid catfish species which is the polychaete specialist of the mangrove system (Krumme et al., 2004; Krumme, unpubl. data). In fact, niche overlap with Cathorops sp. was negligible and restricted to nightly neap tides when $S$. herzbergii was a rare intertidal visitor. Given that food items eaten at spring tides are likely the preferred diet of S. herzbergii, Capitellidae are clearly an evasive food item that is only eaten at neap tides. The sampling, considering the interaction of the tide and the diel cycles, demonstrated that $S$. herzbergii is a benthic predator specialized on Ocypodidae and Grapsidae which are mainly captured during spring tides. (3) Changes in the mortality of prey populations: If food consumption of fishes alters with the spring-neap tide cycle, there may be regular fluctuations in prey mortality. While the preferred prey items of $S$. herzbergii may suffer greater mortality at spring tides, less preferred prey such as Capitellidae may suffer greater mortality at neap tides. Hence, the supply with alternative food organisms may also determine the likelihood of a prey to be eaten. Whether such regular fluctuations really exist and how these may shape the distributions of intertidal prey species and size-classes, remains to be clarified. (4) Modeling of food webs: Trophic models on coasts with pronounced differences between spring and neap tides should take into account that these are systems with two highly disparate conditions. Strong dynamic spring tide periods with higher inundations and current speeds alternate with quieter neap tide periods with lower inundation and current speeds. Focussing on only one part of the cycle (e.g. only on spring tide, but not on neap tide) in a modelling approach may lead to significant misinterpretations of the overall system dynamics (Wolff et al., 2000).

\subsection{Diel cyle}

We assume that the spring-neap alternation is the major cycle controlling changes in access and foraging success for intertidal fishes. Responses to the diel cycle are likely species-specific and depend on the fishes' senses used for foraging and/or on the activity patterns of their prey. In $S$. herzbergii, spring tide prey capture was successful, irrespective of spring high tides occurring at sunrise or sunset. Neither visual conditions (poorer visibility at $\mathrm{SN}$ ) nor the diurnal activity pattern of brachyuran crabs and $P$. gracilis (Koch, 1999) seemed to make a difference in prey availability. The distribution and vertical zonation of ocypodid crabs depends, among other things, on shore level (Koch et al., 2005). In the north Brazilian mangrove, juvenile Uca spp. can be found throughout the intertidal zone with different species occupying the low, mid and high littoral (Koch, 1999). The grapsid $P$. gracilis inhabits the higher intertidal of shady mangrove creeks and is the species that lives lowest in the mangrove forest and is thus most susceptible to piscine predation (Koch, pers. comm.). This suggests that intertidal access beyond a certain shore level in the vertical scale is the crucial parameter controlling successful feeding of S. herzbergii. The four-eyed fish A. anableps encountered best foraging conditions at SD (high inundation, good visibility) but good visual conditions can compensate for low levels of intertidal inundation in visual foragers: ND (low habitat accessibility, but good visibility) and SN (high inundation, poor visibility) ranked second and third while the poorest conditions were encountered at NN (Brenner and Krumme, 2007).

The complete intertidal absence of $S$. herzbergii at ND suggests that ND conditions are unfavorable. Restricted access to the intertidal and the greater visibility at ND may facilitate predator avoidance by the prey organisms. ND conditions prevented not only a major portion of the population of $S$. herzbergii but also kept many other fish species 
from entering the intertidal creeks (Krumme et al., 2004). Whether the fish feed elsewhere or reduce feeding during neap tides is unknown. However, a semi-lunar growth periodicity (Rahman and Cowx, 2006) suggests that the neap tide periods may in fact be linked to reduced food consumption in many intertidal fishes.

\subsection{Intertidal feeding habits}

Sciades herzbergii can be classified as a carnivorous second order consumer. The principal food items Uca spp. and P. gracilis fed exclusively on fine particulate organic matter and small fractions of sediment (Koch, 1999). The mean relative length of the GIT of $S$. herzbergii (1.6) is longer than expected for a carnivorous feeding habit (Odum, 1970). This is likely an adaptation to a diet predominantly composed of hard and soft-shelled benthic invertebrates.

Sciades herzbergii were observed plunging head first into the mud and sucking in the upper sediment layer, likely in an attempt to capture ocypodid crabs. Marks in the mud visible at low tides show the targeted search of $S$. herzbergii for benthic prey during mangrove inundation. Apparently, there is some strategic benefit for at least some fiddler crabs to stay in the entrance of their burrows while the mangrove is flooded.

Unlike benthic ocypodid crabs, arboreal Grapsidae are commonly found living on the stilt roots of $R$. mangle. Grapsidae such as $P$. gracilis are likely captured when submerged at high tides to water their gills. Unlike Bulhosa-Trejo and Mago (1980), no ontogenetic feeding shift was detectable in our samples. Although the creeks are important nursery sites for recently released juveniles (Krumme et al., 2004; Giarrizzo and Krumme, 2007), fish smaller than $10 \mathrm{~cm}$ were not captured due to the mesh size of the net. Giarrizzo and Saint-Paul (2008) showed that juvenile $S$. herzbergii already feed mainly on Ocypodidade and Grapsidae. Mouth-breeding ariids release their young in an advanced stage of development and thus avoid dependency on a special food supply. Nevertheless, we found a positive relationship between fish size and the size of Uca spp. and Grapsidae in the stomachs (Fig. 6). Mortality of prey specimens $>10 \mathrm{~mm}$ carapace width was very low. This could be related (i) to restrictions of gape or prey handling by S. herzbergii, or (ii) larger Grapsidae are capable of better escape and deeper burrows might more effectively protect larger Ocypodidae against predation by S. herzbergii.

The importance of Insecta in the diet of S. herzbergii is likely underestimated due to the presence of low-weight chitin remains in the stomach. However, Insecta likely represent an abundant and nutrient-rich food resource for many mangrove fish (e.g. Robertson, 1988; Krumme et al., 2004; Brenner and Krumme, 2007).

\subsection{Spatial patterns}

There were no significant spatial differences in abundance and feeding of $S$. herzbergii on the scale covered in our study. This is in contrast to the findings for $A$. anableps which were caught together with $S$. herzbergii and had significantly fuller stomachs in the lower creek (Brenner and Krumme, 2007), suggesting that spatial differences in foraging success of fishes are species-specific.

\section{Conclusion}

This is the first study on diel and tidal patterns in feeding of Sciades herzbergii, a carnivorous second order consumer. The catfish mainly fed on Uca spp., Grapsidae and U. cordatus. Sciades herzbergii and the puffer fish Colomesus psittacus (Krumme et al., 2007) are likely the principal natural predators of the ecologically important fiddler crabs (Koch and Wolff, 2002; Koch et al., 2005) and of the economically and ecologically important mangrove crab $U$. cordatus (Schories et al., 2003; Diele et al., 2005). Future studies, e.g. using fish exclosure experiments, will have to determine how piscine predation shapes the distribution and population structure of brachyuran mangrove crabs in time and space.

The spring-neap cycle was the major driver of quantitative and qualitative changes in feeding of $S$. herzbergii on a short- to medium time scale. By controlling the level of the maximum high tide level, the spring-neap cycle regulates the intertidal accessibility and thus, the foraging success of intertidal fishes on macrotidal coasts. This suggests that (i) juvenile fishes have fortnightly growth spurts, (ii) intertidal prey populations may suffer regular fluctuations in mortality, (iii) feeding studies should cover the combined effects of the tidal, diel, lunar and seasonal cycle, and (iv) the modeling of food webs should consider the differences between a highly dynamic spring tide and a quieter neap tide state.

\section{Acknowledgments}

The authors are grateful to Chico, Ilson and A. Echterhoff for assistance in the mangrove. This work resulted from the cooperation between the Center for Tropical Marine Ecology (ZMT), Bremen, Germany and the Univ. Federal do Pará (UFPa), Belém, Brazil, under the Governmental Agreement on Cooperation in the Field of Scientific Research and Technological Development between Germany and Brazil financed by the German Ministry for Education, Science, Research and Technology (BMBF) [Project number: 03F0253A, Mangrove Dynamics and Management - MADAM], and the Conselho Nacional de Pesquisa e Tecnologia (CNPq) [MADAM contribution 115]. [RH]

\section{References}

Barletta, M., Barletta-Bergan, A., Saint-Paul, U., Hubold, G., 2003. Seasonal changes in density, biomass, and diversity of estuarine fishes in tidal mangrove creeks of the lower Caeté Estuary (northern Brazilian coast, east Amazon). Mar. Ecol. Prog. Ser. 256, 217-228

Beyst, B., Vanaverbeke, J., Vincx, M., Mees, J., 2002. Tidal and diurnal periodicity in macrocrustaceans and demersal fish of an exposed sandy beach, with special emphasis on juvenile plaice Pleuronectes platessa. Mar. Ecol. Prog. Ser. 225, 263-274.

Blaber, S.J.M., Brewer, D.T., Salini, J.P., 1995. Fish communities and the nursery role of the shallow inshore waters of a tropical bay in the Gulf of Carpentaria, Australia. Estuar Coast. Shelf Sci. 40, 177-193.

Brenner, M., Krumme, U., 2007. Tidal migration and patterns in feeding of the four-eyed fish Anableps anableps L. in a north Brazilian mangrove. J. Fish Biol. 70 (2), 406-427.

Brenner, M., Buck, B.H., Cordes, S., Dietrich, L., Jacob, U., Mintenbeck, K., Schröder, A. Brey, T., Knust, R., Arntz, W.E., 2001. The role of iceberg scours in niche separation within the Antarctic fish genus Trematomus. Pol. Biol. 24, 502-507.

Brewer, D.T., Blaber, S.J.M., Salini, J.P., 1991. Predation on penaeid prawns by fishes in Albatross Bay, Gulf of Carpentaria. Mar. Biol. 109, 231-240.

Bulhosa-Trejo, A., Mago, L.F., 1980. Feeding of Selenaspis herzbergii during its growth in Tacarigua Lagoon, Venezuela. Memoirs of the 2nd Latin American Symposium on aquaculture, Mexico City (Mexico), 13 Nov 1978, vol. 1, pp. 3067-3101 (in Spanish).

Cannicci, S., Dahdouh-Guebas, F., Anyona, D., Vannini, M., 1996. Natural diet and feeding habits of Thalamita crenata (Decapoda: Portunidae). J. Crust. Biol. 16, 678-683.

Chacon, J.O., Alves, M.I.M., de Mesquita, M.S.C., 1994. Alguns aspectos da reprodução do bagre branco, Selenapsis herzbergii (Bloch 1794), Pisces: Ostariophysi, Siluriformes. Ariidae. Bol. Técnico DNOCS Fortaleza 47/52(1/2), pp. 43-78 (in Portuguese).

Colombini, I., Berti, R., Nocita, A., Chelazzi, L., 1996. Foraging strategy of the mudskipper Periophthalmus sobrinus Eggert in a Kenyan mangrove. J. Exp. Mar. Biol. Ecol. 197 (2), 219-235.

Costello, M.J., 1990. Predator feeding strategy and prey importance: a new graphical analysis. J. Fish Biol. 36, 261-263.

Dalpado, P., Gjøosæter, J., 1988. Feeding ecology of the Laternfish Benthosema pterotum from the Indian Ocean. Mar. Biol. 99, 555-576.

Diele, K., Koch, V., Saint-Paul, U., 2005. Population structure and catch composition of the exploited mangrove crab Ucides cordatus in the Caeté estuary, north Brazil: Indications of overfishing? Aquat. Living Resour. 18 (2), 169-178.

Giarrizzo, T., Krumme, U., 2007. Spatial differences and seasonal cyclicity in the intertidal fish fauna from four mangrove creeks in a salinity zone of the Curuçá estuary, north Brazil. Bull. Mar. Sci. 80 (3), 739-754.

Giarrizzo, T., Saint-Paul, U., 2008. Ontogenetic and seasonal shifts in the diet of the pemecou sea catfish Sciades herzbergii (Siluriformes: Ariidae), from a macrotidal mangrove creek in the Curuçá estuary, Northern Brazil. Rev. Biol. Trop. 56, 861-873.

Gibson, R.N., 1988. Patterns of movement in intertidal fishes. In: Chelazzi, G., Vanini, M. (Eds.), Behavioural adaptions to intertidal life. NATO ASI Series Life Sciences, vol. 151. Plenum Press, London, pp. 55-63.

Gibson, R.N., 1992. Tidally-synchronised behaviour in marine fishes. In: Ali, M.A. (Ed.), Rhythms in Fishes. NATO ASI Series Life Sciences, vol. 236. Plenum Press, New York, pp. 63-81. 
Gibson, R.N., 1996. Tidal, diel and longer term changes in the distribution of fishes on a Scottish sandy beach. Mar. Ecol. Prog. Ser. 130, 1-17.

Gibson, R.N., Pihl, L., Burrows, M.T., Modin, J., Wennhage, H., Nickell, L.A., 1998. Diel movements of juvenile plaice Pleuronectes platessa in relation to predators, competitors, food availability and abiotic factors on a microtidal nursery ground. Mar. Ecol. Prog. Ser. 165, 145-159.

Hamerlynck, O., Cattrijsse, A., Arellano, R.V., 1993. Daily ration of juvenile Pomatoschistus lozanoi de Buen (Pisces: Gobiidae). ICES J. Mar. Sci. 50, 471-480.

Hampel, H., Cattrijsse, A., 2004. Temporal variation in feeding rhythms in a tidal marsh population of the common goby Pomatoschistus microps (Kroyer, 1838). Aquat. Sci. 66, 315-326.

Isaac, V.J., Espirito Santo, R.V., Silva, B.B., Castro, E., Sena, A.L., 2006. Diagnostico da pesca no litoral do estado do Para. In: Isaac, V.J., Martins, A.S., Haimovici, M., Andriguetto, J.M. (Eds.), A pesca marinha e estuarina do Brasil no Início do século XXI: Recursos, tecnologias, aspectos socioeconômicos e institucionais. Editora Universitária Universidade Federal do Pará, Belém, pp. 11-40 (in Portuguese).

Kjerfve, B., Lacerda, L.D., 1993. Mangroves of Brazil. In: Lacerda, L.D. (Ed.), Mangrove ecosystems technical reports. ITTO TS, vol. 13, pp. 245-272.

Kleypas, J., Dean, J.M., 1983. Migration and feeding of the predatory fish, Bairdiella chrysoura Lacépède, in an intertidal creek. J. Exp. Mar. Biol. Ecol. 72, 199-209.

Koch, V., 1999. Epibenthic production and energy flow in the Caeté mangrove estuary, North Brazil. PhD thesis ZMT Contribution No. 6, 97 p.

Koch, V., Wolff, M., 2002. Energy budget and ecological role of mangrove epibenthos in the Caeté estuary, north Brazil. Mar. Ecol. Prog. Ser. 228, 119-130.

Koch, V., Wolff, M., Diele, K., 2005. Comparative population dynamics of four fiddler crabs (Ocypodidae, genus Uca) from a north Brazilian mangrove ecosystem. Mar. Ecol. Prog. Ser. 291, 177-188.

Krumme, U., Saint-Paul, U., Rosenthal, H., 2004. Tidal and diurnal changes in the structure of a nekton assemblage in small intertidal mangrove creeks in northern Brazil. Aquat. Living Resourc. 17, 215-229.

Krumme, U., Keuthen, H., Saint-Paul, U., Villwock, W., 2007. Contribution to the feeding ecology of the banded puffer fish Colomesus psittacus (Tetraodontidae) in north Brazilian mangrove creeks. Brazil. J. Biol. 67 (3), 383-392.

Laroche, J. Baran, E, Rasoanandrasana, N.B. 1997. Temporal patterns in a fish assemblage of a semiarid mangrove zone in Madagascar. J. Fish. Biol. 50 (1), 3-20.
Luengo, J.A., 1973. Apuntes sobre la reproduccion de algunos bagres marinos. Bull. Zool. Mus. Univ. Amst. 3 (8), 47-51 (in Spanish).

Odum, W.E., 1970. Utilization of the direct grazing and plant detritus food chains by the striped mullet Mugil cephalus. In: Steele, J.H. (Ed.), Marine food chains. Oliver and Boyd, Edinburgh, pp. 222-240.

Oliveira, A.M.E., 1972. Peixes estuarinos do nordeste oriental brasileiro. Arq. Cien. Mar. 12, 35-41 (in Portuguese).

Quinn, N.J., Kojis, B.L., 1981. The lack of changes in nocturnal estuarine fish assemblages between new and full moon phases in Serpentine Creek, Queensland. Environ. Biol. Fish 6 (2), 213-218.

Rahman, M.J., Cowx, I.G., 2006. Lunar periodicity in growth increment formation in otoliths of Hilsa shad (Tenualosa ilisha, Clupeidae) in Bangladesh waters. Fish. Res. $81,342-344$.

Robertson, A.I., 1988. Abundance, diet and predators of juvenile banana prawns, $P e-$ naeus merguiensis, in a tropical mangrove estuary. Aust. J. Mar. Freshw. Res. 39, $467-478$.

Rooker, J.R., Dennis, G.D., 1991. Diel, lunar and seasonal changes in a mangrove fish assemblage off southwestern Puerto Rico. Bull. Mar. Sci. 49, 684-698.

Rountree, R.A., Able, K.W., 1993. Diel variarion in decapod and fish assemblages in New Jersey polyhaline marsh creeks. Estuar. Coast. Shelf Sci. 37, 181-201.

Salini, J.P., Brewer, D.T., Blaber, S.J.M., 1998. Dietary studies on the predatory fishes of the Norman River Estuary, with particular reference to penaeid prawns. Estuar. Coast. Shelf Sci. 46, 837-847.

Schories, D., Barletta-Bergan, A., Barletta, M., Krumme, U., Rademaker, V., 2003. The keystone role of leaf-removing crabs in mangrove forests of north Brazil. Wetlands Ecol. Manag. 11, 243-255.

Weisberg, S.B., Whalen, R., Lotrich, V.A., 1981. Tidal and diurnal influence on food consumption of a salt marsh killifish Fundulus heteroclitus. Mar. Biol. 61, 243-246.

Wilson, J.P., Sheaves, M., 2001. Short-term temporal variations in taxonomic composition and trophic structure of a tropical estuarine fish assemblage. Mar. Biol. 139, 878-796.

Wolff, M., Koch, V., Isaac, V., 2000. A trophic flow model of the Caeté mangrove estuary (north Brazil) with considerations for the sustainable use of its resources. Estuar. Coast. Shelf Sci. 50, 789-803. 